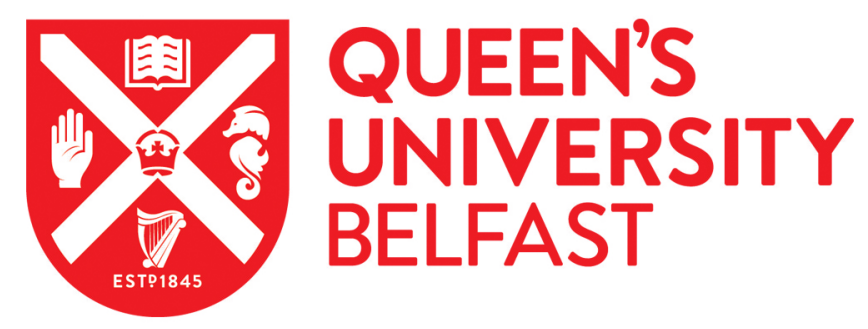

\title{
Providing personalised nutrition: Consumers' trust and preferences regarding sources of information, service providers and regulators, and communication channels Trust and preferences towards personalised nutrition
}

Poinhos, R., Oliveira, B. M. P. M., van der Lans, I. A., Fischer, A. R. H., Berezowska, A., Rankin, A., Kuznesof, S., Stewart-knox, B., Frewer, L. J., \& de Almeida, M. D. V. (2017). Providing personalised nutrition: Consumers' trust and preferences regarding sources of information, service providers and regulators, and communication channels Trust and preferences towards personalised nutrition. Public health genomics, 20(4), 218-228. https://doi.org/10.1159/000481357

Published in:

Public health genomics

Document Version:

Peer reviewed version

Queen's University Belfast - Research Portal:

Link to publication record in Queen's University Belfast Research Portal

\footnotetext{
Publisher rights

Copyright 2017 Karger Publishers. This work is made available online in accordance with the publisher's policies. Please refer to any applicable terms of use of the publisher.
}

\section{General rights}

Copyright for the publications made accessible via the Queen's University Belfast Research Portal is retained by the author(s) and / or other copyright owners and it is a condition of accessing these publications that users recognise and abide by the legal requirements associated with these rights.

Take down policy

The Research Portal is Queen's institutional repository that provides access to Queen's research output. Every effort has been made to ensure that content in the Research Portal does not infringe any person's rights, or applicable UK laws. If you discover content in the

Research Portal that you believe breaches copyright or violates any law, please contact openaccess@qub.ac.uk. 


\section{Providing personalised nutrition: Consumers' trust and preferences regarding sources of information, service providers and regulators, and communication channels}

Rui Poínhos (1*), Bruno MPM Oliveira (1), Ivo A van der Lans (2), Arnout RH Fischer

(2), Aleksandra Berezowska (2), Audrey Rankin (3), Sharron Kuznesof (4), Barbara Stewart-Knox (5), Lynn J Frewer (4), Maria DV de Almeida (1)

(1) Faculty of Nutrition and Food Sciences, University of Porto, Porto, Portugal; (2) Marketing and Consumer Behaviour Group, Wageningen University, Wageningen, The Netherlands; (3) School of Pharmacy, Queens University Belfast, UK; (4) Food and Society Group, Newcastle University, Newcastle Upon Tyne, UK; (5) Psychology, University of Bradford, UK

* Corresponding author: Rui Poínhos; Faculty of Nutrition and Food Sciences, University of Porto, Rua Dr. Roberto Frias - 4200-465 Porto PORTUGAL; phone number: 00351967999221 ; e-mail address: ruipoinhos@fcna.up.pt

Disclosure: The "Food4me" project has received funding from the European Union's Seventh Framework Programme for research, technological development and demonstration (contract number 265 494).

This is a pre-copyedited, author-produced PDF of an article accepted for publication in "Public Health Genomics" following peer review.

\section{Please cite this publication as follows:}

Poínhos R, Oliveira BMPM, van der Lans IA, Fischer ARH, Berezowska A, Rankin A, Kuznesof S, Stewart-Knox B, Frewer LJ, de Almeida MDV. Providing personalised nutrition: Consumers' trust and preferences regarding sources of information, service providers and regulators, and communication channels. Public Health Genomics 2017 (in press). 


\section{Abstract}

Background/Aims: Personalised nutrition has potential to revolutionise dietary health promotion if accepted by the general public. We studied trust and preferences regarding personalised nutrition services, how they influence intention to adopt these services, and cultural and social differences therein.

Methods: A total of 9381 participants were quota sampled to be representative for each of nine EU countries (Germany, Greece, Ireland, Poland, Portugal, Spain, Netherlands, UK, Norway) and surveyed by questionnaire assessing their intention to adopt personalised nutrition, trust in service regulators and information sources, and preferences for service providers and information channels.

Results: Trust and preferences significantly predicted intention to adopt personalised nutrition. Higher trust in the local department of healthcare was associated with lower intention to adopt personalised nutrition. General practitioners were the most trusted of service regulators, except for in Portugal, where consumer organisations and universities were most trusted. In all countries, family doctors were the most trusted information providers. Trust in the National Health Service as service regulator and information source showed high variability across countries. Despite its highest variability across countries, personal meeting was the preferred communication channel except in Spain (where an automated internet service was preferred). General practitioners were the preferred service providers, except in Poland, where dietitians and nutritionists were preferred. The preference for dietitians and nutritionists as service providers highly varied across countries.

Conclusion: These results may assist in informing local initiatives to encourage acceptance and adoption of country specific tailored personalised nutrition services therefore benefiting individual and public health.

Keywords: Personalised nutrition; Genomics; Communication; Regulators; Service providers; Consumers; Trust; Preferences; Food4me 


\section{Introduction}

Personalised nutrition may be defined as nutritional advice based on individual information regarding diet and lifestyle, phenotypic characteristics and/or genetic characteristics [1,2]. Nutritionists and dieticians have typically used (combinations of) information about sex, age, body mass index (BMI), nutritional intake, physical activity and phenotypical characteristics to personalize nutritional advice [3]. Genetic differences, however, also have potential to define to what constitutes an optimal, personalised diet for different individuals (see, inter alia, [4-7]). A greater degree of personalisation can be achieved with analysis of an individual's genotype and phenotype with which diets may interact and co-determine the risk of diet-related diseases [8,9]. Nutrition delivery services and practitioners are beginning to access and use this type of information [10].

There is an emerging body of literature indicating that the level of consumer adoption of gene-based personalised nutrition services will vary between individuals [11-15]. Various socio-demographic, contextual, clinical, personality and/or psychological end-user characteristics (e.g. health commitment, health locus of control, nutrition self-efficacy) have been shown to predict the extent to which individuals are likely to adopt personalised nutrition [14,16-18].

A potentially influential determinant of acceptance is trust in personalised nutrition service providers and in information sources. This has been established in relation to acceptance of different novel food technologies (see, inter alia, $[19,20])$. The extent to which trust influences the acceptance of personalised nutrition based on genomics, however, is less well understood, and may be related to the referred enduser characteristics. The acceptance of personalised nutrition depends on the degree of trust information about data protection and/or health benefits and in those providing this information. Trust in information has been shown to be a determinant of food technology acceptance in previous research [21-23].

Trust in control and regulation will determine the extent to which potential end-users trust those who are delivering the service. Transferring personal data, ensuring data are not misused, interpreting data and generating relevant personalised nutrition advice based on such data is a complex process that cannot be fully controlled by 
the end-user and which may influence whether or not they adopt the service. These issues may become especially important where potential end-users have little experience with an innovation, in which case they tend to rely more on other influential individuals (e.g. regulators and service providers) to protect their interests [22]. This implies that for the acceptance and adoption of personalised nutrition, trust in regulatory institutions and service providers is required [23-27].

Consumers' trust towards food information is higher when it is disseminated by public or social institutions than when by private bodies [28]. Trust in regulators and providers to deliver a safe and effective service has emerged as a central issue for the acceptance and adoption of personalised nutrition [14,16,21]. In the case of personalised nutrition services, trust in providers to protect data was considered important in choosing a service provider and that not all personalised nutrition service providers are equally trusted [14]. Participants were more confident in services provided by health professionals [16,29]. The presence of a "named individual", preferably a fully qualified health professional, served as a cue that the provider was trustworthy [14].

In order to adopt personalised nutrition, there is evidence that end-users have to be confident about the security-related efficacy of the communication channels [14]. Some end-users may, for instance, be concerned about the extent to which online communication lacks security for transmitting and storing phenotypic or genetic data. Some end-users remain cautious about the extent to which they may trust on the accuracy and credibility of online health information [30,31]. Hence, there may be individual differences in preference for communication channels used to convey information about personalised nutrition and these preferences may be driven by the perception of trust.

End-users from different socio-demographic groups may differ in the extent to which they trust service providers, regulators and online delivery of information. Therefore, preferences for how, and by whom, personalised nutrition services should be provided may differ between countries and cultural contexts, even when regulations in these countries are very similar, or regulation is centralised across a region. The European Union (EU) provides an excellent opportunity to explore this further, as member countries share a common regulatory regime regarding food safety 
standards and implementation ("The European Food Law"; http://ec.europa.eu/food/food/foodlaw/index_en.htm), while differences in public trust in the regulatory systems differs across countries, including at the regional level [32]. For instance, research on trust in information sources about fish [33] has revealed sociodemographic differences.

The current paper aims to study trust and preferences regarding personalised nutrition service providers, regulators, information sources, and information channels, and to understand how they influence the intention to adopt personalised nutrition services. It also studies how cultural and social differences between individuals in different EU countries may influence intention through differences in trust. This knowledge may assist in informing local initiatives to encourage acceptance and adoption of country specific tailored personalised nutrition services and, therefore, benefit individual and public health.

Therefore, and in order to explore how service characteristics may influence the intention to adopt personalised nutrition, the objectives of this paper are: (a) to assess socio-demographic differences (country, sex, age, and education) in trust in personalised nutrition service regulators, trust in personalised nutrition information providers, preferences for personalised nutrition communication channels and preferences for personalised nutrition service providers; and, (b) to study the influence of trust in personalised nutrition service regulators, trust in personalised nutrition information providers, preferences for personalised nutrition communication channels and preferences for personalised nutrition service providers on their intention to adopt personalised nutrition services.

\section{Methods}

\section{Participants and procedure}

Ethical approval was granted by the lead academic institution. A survey was conducted across nine EU countries: Germany, Greece, Ireland, Poland, Portugal, Spain, the Netherlands, the UK, and Norway. A total of 9381 participants were quota sampled to be nationally representative for each country in terms of sex, age group (18 to 29,30 to 39,40 to 54 , and 55 to 65 years) and education level (highest level of 
education completed based on International Standard Classification of Education levels: ISCED 0 to 2, ISCED 3 or 4, and ISCED 5 or 6). Table 1 summarises the sample characteristics by country (see also [17], in which the same sample was used). Participants were drawn from an existing panel of a social research agency (GfK), and additional research agencies were subcontracted by the primary agency to supplement panels where needed. A total of 29,450 individuals were contacted, being the overall response rate $31.9 \%$. Data were collected in February and March 2013, using an on-line survey. After reading an introductory text, participants provided informed consent prior to completing the questionnaire.

\section{* * * Insert Table 1 here * *}

\section{Questionnaire development}

The details of questionnaire development and piloting are provided by [17]. At the beginning of the questionnaire a definition of personalised nutrition was provided, as follows: "We would like to draw your attention to the definition of personalised nutrition which is 'healthy eating advice that is tailored to suit an individual based on their own personal health status, diet, physical activity and/or genetics". The questionnaire was pretested using face-to-face interviews in the UK $(n=16)$ to determine question comprehension and the amount of time needed to complete the questionnaire. After pretesting, the questionnaire was refined and piloted online in the UK $(n=50)$, and Portugal $(n=50)$, using Survey Monkey (http://www.surveymonkey.com). After the pilots, minor changes to question order were made to mitigate framing effects, and some items specifically developed for this survey were reworded where needed. The questionnaire was then translated into the native languages of each of the countries involved in the study. Translations were checked by back-translation to ensure equivalence across countries.

The variables, items and response scales included in the current study are presented in Table 2. Most items were informed by the results of prior focus group studies [14]. The intention to adopt personalised nutrition services was a future behaviour adapted version $[34,35]$ of the items used by [36]. 


\section{Data analysis}

All statistical analyses were performed in IBM SPSS 21.0 for Windows; $p$-values below 0.05 were interpreted as statistically significant. To have at least some practical purpose, the relevance of explained variances below $1 \%$ was considered to be negligible (cf. $[37,38]$ ), and therefore the interpretation of results will not focus on those values. Intention to adopt personalised nutrition showed high reliability (Cronbach's alpha $=0.922$ ), allowing to use the sum of the items as single indicator for intention. A linear regression model was estimated to predict intention to take up personalised nutrition based on trust in personalised nutrition service regulators and personalised nutrition information providers, and preferences for personalised nutrition communication channels and personalised nutrition service providers. This analysis was performed using all 32 items included as independent variables, and with intention to take up personalised nutrition (sum of the 3 items) as the dependent variable. Multicollinearity was checked using variance inflation factor, which showed acceptable values (below 5) for all independent variables.

Repeated-measures ANOVA were used to study socio-demographic (i.e. country, sex, age group, and education level) differences in each of four groups of variables: (1) trust in regulators, (2) trust in information sources, (3) preferences for communication channel, and (4) preferences for service providers. Significant and non-negligible differences were further investigated using simple effects analysis.

\section{Results}

The 32 trust and preference items significantly predicted intention to adopt personalised nutrition $\left(\mathrm{F}(32,9348)=72.401, p<0.001\right.$, adjusted $\left.\mathrm{R}^{2}=0.196\right)$. Based on the standardized regression coefficients the strongest predictors of intention to adopt personalised nutrition were greater trust in dietitians/ nutritionists as service providers, the European Commission as service regulator, online personalised nutrition companies as information source on personalised nutrition and email contacts from named people as communication channel. Higher trust in the local 
department of healthcare was associated with significantly lower intention to adopt personalised nutrition (see Table 3 for a full overview of coefficients).

\section{*** Insert Table 3 here ** *}

Repeated-measures ANOVA showed several significant effects of sociodemographics, service providers, and information sources (Table 4 and 5), but most effect sizes were negligible (partial $\eta^{2}<0.01$ ). Between-subjects country effects were higher for communication channels (partial $\eta^{2}=0.052$ ) and service providers (partial $\eta^{2}=0.042$ ) than for service regulators (partial $\eta^{2}=0.013$ ); or information providers (partial $\eta^{2}=0.018$ ); the effect of age for communication channels was also nonnegligible (partial $\eta^{2}=0.015$ ). Relevant source within-subjects effects were found for all four groups of variables (partial $\eta^{2}$ between 0.118 and 0.297 ), as well as source*country interactions (partial $\eta^{2}$ between 0.015 and 0.036 ).

\section{*** Insert Tables 4 and 5 here ***}

Given the overall aim and objectives of our study, driven by the fact that the items on preference in communication channels and service providers are in part mutually exclusive and do not constitute constructs, there is only minimal value in interpreting the overall effects of country, sex or age group on these preferences. Country, sex and age main effects, therefore, were analyzed only for trust in service regulators and information providers.

Spanish and German participants showed the highest mean level of trust across personalised nutrition service regulators, followed by Dutch, Norwegian, Irish, Portuguese, UK, Polish and Greek participants (Table 6). For overall trust in information provision, negligible effect sizes indicated that Spain showed the highest mean trust, followed by Portugal, Ireland, Germany, Netherlands, UK, Poland, Norway and Greece.

\section{*** Insert Table 6 here ***}

Regarding sex and age group, although there were significant main effects on the overall trust measures, such that females (vs. males) had higher overall level of trust 
in information providers, and younger (vs. older) participants had higher overall trust in regulators and information providers The effect sizes, however, were negligible (partial $\left.\eta^{2}<0.01\right)$.

\section{Country $x$ Source}

Table 7 presents the observed means for preferences towards each actor, or communication channel per country, as well as homogeneous subsets of actors or communication channels (per country; Tukey HSD) and countries (per item; Sidak).

\section{Trust in regulation}

General practitioners (GPs) were the most trusted potential regulators in most countries, except for Portugal, where consumer organisations and universities were most trusted. Among Greek and Norwegian participants, the preference for universities (Greece) and consumer organisations (Norway) was not significantly lower than for GPs'. Trust in the Department of Health/ National Health Service and health insurance companies varied most across countries. The Department of Health was most trusted in Norway and in the UK, and least trusted in Greece. Germans trusted health insurance companies most as consumer protection sources, whereas Greek, Polish and Portuguese participants indicated the lowest level of trust in this source.

\section{Trust in information provider}

In all countries, family doctors were the most trusted information providers. In some countries, some other information providers did not significantly differ from family doctors: the National Health Service (Germany and Poland), dietitians/ nutritionists (Norway and Poland), and friends and family (Poland). Similarly to what was found for consumer protection, trust in national health services as an information source showed high variability, being the highest rated in Germany and the lowest in the Netherlands.

\section{Preference for communication channel}


Personal meeting was the most preferred communication channel in most countries. Among German participants, the preference for this communication channel was not significantly different from an email contact from a named person. Spain was the only country in which the preferred communication channel was an automated internet service. Despite the overall preference towards personal meetings, this communication channel showed the highest variability across countries.

\section{Preference for service provider}

As for service providers, dietitians and nutritionists were the source for which preference varied most across countries. Germans preferred these professionals least, while Greek participants showed the highest level of preference for them. Moreover, dietitians and nutritionists were the preferred service providers in Poland, whereas in all other countries participants preferred family doctors/ GP.

*** Insert Table 7 here ***

\section{Discussion}

This study implies that consumer trust in, and preference for, personalised nutrition services represent a significant and relevant predictor of their intention to adopt these services. The regression model indicated that sources of information, service providers and regulators, and communication channels together predicted about one fifth of the variance of the behavioral intention. This is in line with prior research showing that trust in different services and their features predicts intention to adopt various technologies [16,22-27], and highlights the relevance of this study.

Sociodemographic differences have been found for trust in information sources about food-related issues [33]. In our study, trust in national health service as a service regulator and information provider, and in dietitians and nutritionists, as service providers were those which most varied between countries. This might be explained by health inequalities between countries in both health epidemiology and health service characteristics $[39,40]$. The importance of trust as a predictor for the intention to adopt personalised nutrition services and the relevant country differences suggest that tailoring regulation, information provision, service provider, and communication channel to fit local preference may be a worthwhile effort. For example, while in many 
countries a personal meeting appears the only viable option, in Spain e-mail contact may be sufficient. Also, research has suggested that trust in both information and service providers is shaped by historical and cultural experiences, in particular in the agrifood sector where there has been a long history of food scares (e.g. [32,41]). Nevertheless, our overall results are in line with those indicating higher consumers' trust on public than private institutions [28].

Despite greater preference for personal meetings in order to receive personalised nutrition advice, this communication channel was the one with the highest intercountry variability. However, among communication channels, the strongest predictor of intention to adopt personalised nutrition was email contacts from named people, such as the family doctor. Prior findings suggest that online personalised nutrition companies, based on email contacts instead of personal meetings, are preferred by some groups owing to the anonymity and convenience associated with these features $[14,16,29,42]$.

That high trust in national healthcare was associated with low intention to adopt personalised nutrition was unexpected. An explanation may be that some of the benefits from potential personalised nutrition users are not "classical" health issues (such as disease prevention or treatment), but also focus on prevention, fitness and quality of life [14,42]. High trust in the department of health may therefore be related to an individual's health motivation to follow the classical health perspective, which would be based in trust in healthcare departments but go against the adoption of non-traditional personalised nutrition services. On the other hand, individuals who focused on issues traditionally not covered by national health services may be more likely to adopt personalised nutrition. Some people may assume that their health services currently do not support personalised nutrition, and/or that the currently advocated approaches are sufficient.

Country differences in trust and preferences were larger than those of other sociodemographic factors (sex, age, and education), suggesting that country-specific cultural factors could be more relevant than sociodemographics. This again may depend on how regulators have been perceived to handle food scares in a particular country or region in the past (e.g. see inter alia, [43]). Spanish and German participants showed the highest mean trust across personalised nutrition service 
regulators, followed by Dutch, Norwegian, Irish, Portuguese, UK, Polish and Greek participants. For overall trust in information provision negligible effects sizes indicated that Spain showed the highest mean trust, followed by Portugal, Ireland, Germany, Netherlands, UK, Poland, Norway and Greece. These between-country differences may contribute to the possible explanations presented for the relation between high trust in national health services and low intention to adopt personalised nutrition.

There may be a disconnection between self-reported behavioural measures and adoption of specific consumer behaviors. At a very general level, this has been exemplified by the differences in self-reported consumer behaviours expressed by citizens, and associated consumer behaviours, across a wide range of agrifood issues (e.g. [44]). It is therefore possible that trust in information and trust in societal entities are not good indicators of consumer behavior. Other constructs and variables, such as willingness-to-pay (WTP) for a personalised nutrition services, appear to offer different interpretations of behavioral intention to adopt (e.g. [45]). The most reliable indicator will be the actual adoption of personalised nutrition services, and in the future research might validate proxy measures such as social trust, trust in information sources, or WTP, against actual behavior.

Some limitations must be considered, namely the compliance rate $(31.9 \%)$, which may somewhat constrain the generalization of results. Besides the large sample size, quota sampling used to achieve national representativeness decreases any potential bias because of this limitation. Nevertheless, potential sampling bias should be taken into account, as for example regarding country variations in the participants' level of education.

Another possible limitation is that, because personalised nutrition will have been a relatively unfamiliar service with which the general public will have had little or no direct experience, some of the trust and preferences' results may not have been specific to personalised nutrition. This lack of direct experience may contribute to the apparent similarity of these results with those found for other services. For instance, our results on socio-demographic differences in preferences and trust in service characteristics are in line with several studies, indicating a consumer preference for the provision of such services to be based on the existing health systems. The different levels of preference and trust for different services is possibly due to the 
trust consumers' have on well-known institutions and professional groups [46-48], especially regarding innovative services, such as personalised nutrition [22]. Overall, participants from the countries included in the research preferred family doctors/ GPs as information and service providers, as well as regulators, and personal meetings was the preferred communication channel. 


\section{References}

1. Celis-Morales C, Livingstone KM, Marsaux CF, Forster H, O'Donovan CB, Woolhead C, Macready AL, Fallaize R, Navas-Carretero S, San-Cristobal R, Kolossa S, Hartwig K, Tsirigoti L, Lambrinou CP, Moschonis G, Godlewska M, Surwiłło A, Grimaldi K, Bouwman J, Daly EJ, Akujobi V, O’Riordan R, Hoonhout J, Claassen A, Hoeller U, Gundersen TE, Kaland SE, Matthews JN, Manios Y, Traczyk I, Drevon CA, Gibney ER, Brennan L, Walsh MC, Lovegrove JA, Martinez AJ, Saris WH, Daniel H, Gibney M, Mathers JC: Design and baseline characteristics of the Food4me study: a web-based randomised controlled trial of personalised nutrition in seven European countries. Genes Nutr 2015;10:450.

2. Ferguson L, Bishop K, Karunsinghe N: Impact of personalized nutrition on public health. In: Ghosh D, Bagchi D, Konishi T (editors): Clinical Aspects of Functional Foods Nutraceuticals, 2014, p. 371.

3. Boland $\mathrm{M}$ : Innovation in the food industry. Personalised nutrition and mass customisation. Innov Organ Manag 2008;10(1):53-60.

4. Casper J: Epigenetics, Nutrigenomics, and Genetic Testing. 2016. Available from: http://nutritionalbalancing.org/center/htma/science/articles/epigenetics.php.

5. Fenech M: Nutrigenomics and Nutrigenetics: The new paradigm for optimising health and preventing disease. J Nutr Sci Vitaminol 2015;61(suppl):S209.

6. Horne J, Madill J, O'Connor C: Nutrigenomics: An evident need for education in the field of dietetics. Can J Diet Pract Res 2015, 76(3):pe9.

7. Madden J, Williams CM, Calder PC, Lietz G, Miles EA, Cordell H, Mathers JC, Minihane AM: The impact of common gene variants on the response of biomarkers of cardiovascular disease (CVD) risk to increased fish oil fatty acids intakes. Ann Rev Nutr 2011;31:203-234.

8. Ouhtit A: Nutrigenomics: From promise to practice. Sultan Qaboos Univ Med J 2014;14(1):e1-e3. 
9. Vergères G: Nutrigenomics - Linking food to human metabolism. Trends Food Sci Tech 2013;31(1):6-12.

10. Abrahams M, Frewer L, Stewart-Knox B: Factors determining the integration of nutritional genomics into clinical practice by registered dietitians. Trends Food Sci Technol 2017;59:139-147.

11. Rankin A, Kuznesof S, Frewer LJ, Orr K, Davison J, de Almeida MD, StewartKnox B. Public perceptions of personalised nutrition through the lens of Social Cognitive Theory. J Health Psychol 2016 [Epub ahead of print].

12. Ronteltap A, van Trijp H, Berezowska A, Goossens J: Nutrigenomics-based personalised nutritional advice: In search of a business model? Genes Nutr 2013;8(2):153-163.

13. Fallaize R, Macready AL, Butler LT, Ellis JA, Lovegrove JA: An insight into the public acceptance of nutrigenomic-based personalised nutrition. Nutr Res Rev 2013;26(1):39-48.

14. Stewart-Knox B, Kuznesof S, Robinson J, Rankin A, Orr K, Duffy M, Poínhos R, de Almeida MDV, Macready A, Gallagher C, Berezowska A, Fischer ARH, NavasCarretero S, Riemer M, Traczyk I, Gjelstad IMF, Mavrogianni C, Frewer LJ: Factors influencing European consumer uptake of personalised nutrition. Results of a qualitative analysis. Appetite 2013;66:67-74.

15. Stewart-Knox BJ, Bunting BP, Gilpin S, Parr HJ, Pinhão S, Strain JJ, de Almeida MD, Gibney M: Attitudes toward genetic testing and personalised nutrition in a representative sample of European consumers. Brit J Nutr 2009;101,982-989.

16. Berezowska A, Fischer ARH, Ronteltap A, Kuznesof S, Macready A, Fallaize R, van Trijp HCM: Understanding consumer evaluations of personalised nutrition services in terms of the privacy calculus: A qualitative study. Public Health Genomics $2014 ; 17(3): 127-140$.

17. Poínhos $R$, van der Lans IA, Rankin A, Fischer $A R H$, Bunting $B$, Kuznesof $S$, Stewart-Knox B, Frewer L: Psychological determinants of consumer acceptance of 
personalised nutrition in 9 European countries; the importance of perceived benefit. PLos ONE 2014;9(10):e110614.

18. Ronteltap A, van Trijp JCM, Renes RJ: Consumer acceptance of nutrigenomicsbased personalised nutrition. Brit J Nutr 2009;101(1):132-144.

19. Giles EL, Kuznesof S, Clark B, Hubbard C, Frewer LJ: Consumer acceptance of and willingness to pay for food nanotechnology: a systematic review. J Nanopart Res 2015;17(12):1-26.

20. Roosen J, Bieberstein A, Blanchemanche S, Goddard E, Marette S, Vandermoere F: Trust and willingness to pay for nanotechnology food. Food Policy 2015;52:75-83.

21. Berezowska A, Fischer AR, Ronteltap $A$, van der Lans $I A$, van Trijp $H C$ : Consumer adoption of personalised nutrition services from the perspective of a riskbenefit trade-off. Genes Nutr 2015;10(6):42.

22. Siegrist M, Cvetkovich G: Perception of hazards. The role of social trust and knowledge. Risk Anal 2000;20(5):713-719.

23. Siegrist M, Cvetkovich G, Roth C: Salient value similarity, social trust, and risk/benefit perception. Risk Anal 2000;20(3):353-362.

24. Popa ME, Popa A: Consumer behavior: Determinants and trends in novel food choice; in McElhatton A, Sobral PJA (eds): Novel Technologies in Food Science New York: Springer, 2012, pp 137-156.

25. Frewer LJ, Bergmann B, Brennan M, Lion R, Meertens R, Rowe G, Siegrist M, Vereijken C: Consumer response to novel agri-food technologies. Implications for predicting consumer acceptance of emerging food technologies. Trends Food Sci Technol 2011;22(8):442-456.

26. Costa-Font M, Gil JM: Structural equation modelling of consumer acceptance of genetically modified (GM) food in the Mediterranean Europe: A cross country study. Food Qual Prefer 2009;20(6):399-409. 
27. Poortinga W, Pidgeon NF: Exploring the dimensionality of trust in risk regulation. Risk Anal 2003;23(5):961-972.

28. Nocella G, Romano D, Stefani G: Consumers' attitudes, trust and willingness to pay for food information. Int J Consum Stud 2014;38(2):153-165.

29. Fallaize R, Macready AL, Butler LT, Ellis JA, Berezowska A, Fischer ARH, Walsh M, Gallagher C, Stewart-Knox BJ, Kuznesof S, Frewer L, Gibney M, Lovegrove JA: The perceived impact of the National Health Service on personalised nutrition service delivery among the UK public. Brit J Nutr 2015;8:1271-1279.

30. Xiao N, Sharman R, Rao HR, Upadhyaya S: Factors influencing online health information search: An empirical analysis of a national cancer-related survey. Decis Support Syst 2014;57:417-427.

31. Rutsaert P, Regan A, Pieniak Z, McConnon A, Moss A, Wall P, Verbeke W: The use of social media in food risk and benefit communication. Trends Food Sci Tech 2013;30(1):84-91.

32. van Kleef E, Frewer LJ, Chryssochoidis GM, Houghton JR, Korzen-Bohr S, Krystallis T, Lassen J, Pfenning U, Rowe G: Perceptions of food risk management among key stakeholders: Results from a cross-European study. Appetite 2006;47(1):46-63.

33. Pieniak Z, Verbeke W, Scholdered J, Brunso K, Olsen SO: European consumers' use and trust in information sources about fish. Food Qual Pref 2007;18(8):10501063.

34. Melnyk V, van Herpen E, Fischer AR, van Trijp, $H$ : To think or not to think: the effect of cognitive deliberation on the influence of injunctive versus descriptive social norms. Psychol Market 2011;28(7):709-729.

35. Oliver RL, Rust RT, Varki S: Customer delight: foundations, findings, and managerial insight. J Retailing 1997;73(3):311-336.

36. Ajzen I: The theory of planned behavior. Organ Behav Hum Decis Process $1991 ; 50(2): 179-211$. 
37. Cohen J: Statistical power analysis for the Behavioral Sciences, 2nd ed. New Jersey: Lawrence Erlbaum Associates, 1988.

38. Cohen J: A power primer. Psychol Bull 1992;112(1):155-159.

39. Divajeval D, Marsh T, Logstrup S, Kestens M, Vemer P, Kriaucioniene V, Peresson S, O'Kelly S, Rito A, Webber L: Economics of chronic diseases protocol: Cost-effectiveness modeling and the future burden of non-communicable disease in Europe. BMC Public Health 2014;14:456.

40. UCL Institute of Health Equity: Review of social determinants and the health divide in the WHO European region: Final report. 2013. Available from: http://www.euro.who.int/en/health-topics/health-policy/health-2020-the-europeanpolicy-for-health-and-well-being/publications/2013/review-of-social-determinants-andthe-health-divide-in-the-who-european-region.-final-report.

41. Houghton JR, van Kleef E, Rowe G, Frewer LJ: Consumer perceptions of the effectiveness of food risk management practices: A cross-cultural study. Health Risk Soc 2006;8(2):165-183.

42. Stewart-Knox B, Rankin A, Kuznesof S, Poínhos R, de Almeida MDV, Fischer A, Frewer L: Promoting healthy dietary behaviour through personalised nutrition: Technology push or technology pull? Proceedings of the Nutrition Society 2015;74:171-176.

43. Eiser JR, Miles S, Frewer LJ: Trust, perceived risk, and attitudes toward food technologies. J Appl Soc Psychol 2002;32(11):2423-2433.

44. de Bakker E, Dagevos H: Reducing meat consumption in today's consumer society: questioning the citizen-consumer gap. J Agr Envir Ethics 2012;25(6):877894.

45. Fischer $A R H$, Berezowska A, van der Lans IA, Ronteltap A, Rankin A, Kuznesof S, Poínhos R, Stewart-Knox B, Frewer LJ: Willingness to pay for personalised nutrition across Europe. Eur J Public Health 2016;26(4):640-644. 
46. Wendel S, Dellaert BGC, Rosentalp A, van Trijp HCM: Consumers' intention to use health recommendation systems to receive personalised nutrition advice. BMC Health Serv Res 2013;13:126.

47. Pavlidis C, Karamitri A, Barakou A, Cooper DN, Poulas K, Topouzis S, Patrinos GP: Ascertainment and critical assessment of the views of the general public and healthcare professional on nutrigenomics in Greece. Pers Med 2012;9:201-210.

48. Su H-L, Lu T-J: Exploring the consumer acceptance of and preferences in nutrigenomics-based personalized health management service. PIMTEC 12: Proceedings - Technology Management for Emerging Technologies 2012:30503058. 
Table 1. Sample profile

\begin{tabular}{|c|c|c|c|c|c|c|c|c|c|c|c|}
\hline & & $\begin{array}{l}\text { Germany } \\
(n=1020)\end{array}$ & $\begin{array}{c}\text { Greece } \\
(n=1020)\end{array}$ & $\begin{array}{l}\text { Ireland } \\
(n=1020)\end{array}$ & $\begin{array}{l}\text { Netherlands } \\
\quad(n=1020)\end{array}$ & $\begin{array}{l}\text { Norway } \\
(n=1022)\end{array}$ & $\begin{array}{l}\text { Poland } \\
(n=1045)\end{array}$ & $\begin{array}{l}\text { Portugal } \\
(n=1148)\end{array}$ & $\begin{array}{c}\text { Spain } \\
(n=1025)\end{array}$ & $\begin{array}{c}\text { UK } \\
(n=1061)\end{array}$ & $\begin{array}{c}\text { TOTAL } \\
(n=9381)\end{array}$ \\
\hline SEX & male & 49.9 & 49.4 & 49.8 & 50.3 & 52.6 & 52.1 & 49.5 & 51.3 & 51.0 & 50.6 \\
\hline \multirow{4}{*}{ AGE } & $18-29$ y $\%$ & 18.6 & 24.7 & 23.5 & 20.0 & 20.5 & 24.4 & 23.8 & 19.0 & 23.0 & 22.0 \\
\hline & $30-39$ y $\%$ & 16.4 & 32.1 & 26.4 & 18.3 & 21.6 & 23.9 & 25.7 & 26.6 & 19.4 & 23.4 \\
\hline & $40-54$ у $\%$ & 40.5 & 37.6 & 32.1 & 38.2 & 30.7 & 28.0 & 34.8 & 35.4 & 36.0 & 34.8 \\
\hline & $55-65$ y $\%$ & 24.5 & 5.6 & 18.0 & 23.4 & 27.1 & 23.6 & 15.7 & 18.9 & 21.6 & 19.8 \\
\hline \multirow{3}{*}{ EDUCATION } & Low & 29.6 & 31.5 & 12.2 & 28.8 & 38.8 & 11.2 & 24.9 & 32.3 & 49.0 & 28.7 \\
\hline & Middle & 52.9 & 35.2 & 37.5 & 35.6 & 31.2 & 61.3 & 37.9 & 43.2 & 15.4 & 38.9 \\
\hline & High $\%$ & 17.5 & 33.3 & 50.4 & 35.6 & 29.9 & 27.5 & 37.2 & 24.5 & 35.6 & 32.4 \\
\hline
\end{tabular}


Table 2. Variables, questions, items and response modes

\begin{tabular}{|c|c|c|c|}
\hline Variables & Question asked & Items & Response \\
\hline $\begin{array}{l}\text { Intention to } \\
\text { adopt } \\
\text { personalised } \\
\text { nutrition }\end{array}$ & $\begin{array}{l}\text { Please indicate the extent to } \\
\text { which you agree or disagree } \\
\text { with the following statements: }\end{array}$ & $\begin{array}{l}\text { 3 items: } \\
\text { - I intend to adopt personalised nutrition. } \\
\text { - I would consider adopting personalised nutrition. } \\
\text { - I am definitely going to adopt personalised nutrition }\end{array}$ & $\begin{array}{l}1=\text { Completely disagree } \\
2=\text { Disagree } \\
3=\text { Neither agree nor } \\
\text { disagree } \\
4=\text { Agree } \\
5=\text { Completely agree }\end{array}$ \\
\hline $\begin{array}{l}\text { Trust in } \\
\text { different } \\
\text { personalised } \\
\text { nutrition } \\
\text { service } \\
\text { regulators }\end{array}$ & $\begin{array}{l}\text { Please indicate the extent to } \\
\text { which you trust each of the } \\
\text { following organisations to } \\
\text { protect consumers in relation } \\
\text { to personalised nutrition } \\
\text { services: }\end{array}$ & $\begin{array}{l}8 \text { items: } \\
\text { - The Department of Health/ National Health Service } \\
\text { (NHS) } \\
\text { - The European Commission } \\
\text { - General practitioners (GPs) } \\
\text { - Food manufacturers } \\
\text { - Food retailers } \\
\text { - Consumer organisations } \\
\text { - Universities } \\
\text { - Health insurance companies }\end{array}$ & \multirow[b]{2}{*}{$\begin{array}{l}1=\text { Distrust extremely } \\
2=\text { Distrust } \\
3=\text { Neither trust nor distrust } \\
4=\text { Trust } \\
5=\text { Trust extremely }\end{array}$} \\
\hline $\begin{array}{l}\text { Trust in } \\
\text { different actors } \\
\text { to provide } \\
\text { accurate } \\
\text { information } \\
\text { about } \\
\text { personalised } \\
\text { nutrition }\end{array}$ & $\begin{array}{l}\text { Please indicate the extent to } \\
\text { which you trust each of the } \\
\text { following information sources } \\
\text { to provide accurate } \\
\text { information about } \\
\text { personalised nutrition: }\end{array}$ & $\begin{array}{l}\text { 14 items: } \\
\text { - Your family doctor } \\
\text { - Department of Health } \\
\text { - The European Commission } \\
\text { - National Health Service (NHS) } \\
\text { - Food retailers } \\
\text { - Food manufacturers } \\
\text { - Online personalised nutrition companies } \\
\text { - Universities } \\
\text { - Consumer organisations } \\
\text { - Dieticians/ nutritionists } \\
\text { - Personal trainers } \\
\text { - Friends and family } \\
\text { - News media } \\
\text { - Social media }\end{array}$ & \\
\hline $\begin{array}{l}\text { Preferences } \\
\text { regarding } \\
\text { personalised } \\
\text { nutrition } \\
\text { communication } \\
\text { channels }\end{array}$ & $\begin{array}{l}\text { Please indicate the extent to } \\
\text { which you would prefer } \\
\text { personalised nutrition to be } \\
\text { provided through the following } \\
\text { communication channels: }\end{array}$ & $\begin{array}{l}6 \text { items: } \\
\text { - Email contact from a named person } \\
\text { - Automated internet service } \\
\text { - Telephone call } \\
\text { - Video call (e.g. Skype) } \\
\text { - Personal meeting } \\
\text { - Apps }\end{array}$ & \multirow{2}{*}{$\begin{array}{l}1=\text { Not at all } \\
2=\text { Slightly } \\
3=\text { Moderately } \\
4=\text { Very } \\
5=\text { Extremely }\end{array}$} \\
\hline $\begin{array}{l}\text { Preferences } \\
\text { regarding } \\
\text { personalised } \\
\text { nutrition } \\
\text { service } \\
\text { providers }\end{array}$ & $\begin{array}{l}\text { Please indicate the extent to } \\
\text { which you would prefer the } \\
\text { following people or } \\
\text { organisations to provide a } \\
\text { personalised nutrition service: }\end{array}$ & $\begin{array}{l}4 \text { items: } \\
\text { - Family doctor/GP } \\
\text { - Private health organisations } \\
\text { - Dietician/ Nutritionist } \\
\text { - Supermarket }\end{array}$ & \\
\hline
\end{tabular}


Table 3. Standardized regression coefficients for items predicting intention to adopt personalised nutrition

\begin{tabular}{|c|c|c|}
\hline & $\begin{array}{l}\text { Standardized } \\
\text { regression } \\
\text { coefficients }\end{array}$ & $p$ \\
\hline \multicolumn{3}{|l|}{$\begin{array}{l}\text { Trust in different personalised nutrition service regulators } \\
\text { (consumer protection) }\end{array}$} \\
\hline The Department of Health/ National Health Service (NHS) & -0.045 & 0.007 \\
\hline The European Commission & 0.103 & $<0.001$ \\
\hline General practitioners (GPs) & 0.005 & 0.685 \\
\hline Food manufacturers & 0.009 & 0.615 \\
\hline Food retailers & -0.023 & 0.195 \\
\hline Consumer organisations & -0.030 & 0.038 \\
\hline Universities & 0.025 & 0.113 \\
\hline Health insurance companies & -0.006 & 0.614 \\
\hline \multicolumn{3}{|c|}{$\begin{array}{l}\text { Trust in different actors to provide accurate information about } \\
\text { personalised nutrition }\end{array}$} \\
\hline Your family doctor & 0.017 & 0.197 \\
\hline Department of Health & -0.062 & $<0.001$ \\
\hline The European Commission & 0.016 & 0.374 \\
\hline National Health Service (NHS) & 0.033 & 0.009 \\
\hline Food retailers & -0.031 & 0.103 \\
\hline Food manufacturers & 0.011 & 0.572 \\
\hline Online personalised nutrition companies & 0.095 & $<0.001$ \\
\hline Universities & -0.032 & 0.053 \\
\hline Consumer organisations & -0.004 & 0.806 \\
\hline Dieticians/ nutritionists & 0.017 & 0.212 \\
\hline Personal trainers & 0.064 & $<0.001$ \\
\hline Friends and family & 0.025 & 0.022 \\
\hline News media & 0.002 & 0.872 \\
\hline Social media & 0.045 & 0.001 \\
\hline \multicolumn{3}{|c|}{$\begin{array}{l}\text { Preferences regarding personalised nutrition communication } \\
\text { channels }\end{array}$} \\
\hline Email contact from a named person & 0.095 & $<0.001$ \\
\hline Automated internet service & 0.039 & 0.004 \\
\hline Telephone call & -0.012 & 0.389 \\
\hline Video call (e.g. Skype) & 0.024 & 0.079 \\
\hline
\end{tabular}


Poínhos et al. (2017). Trust and preferences towards personalised nutrition

\begin{tabular}{|l|c|c|}
\hline Personal meeting & 0.079 & $<0.001$ \\
\hline Apps & 0.011 & 0.379 \\
\hline Preferences regarding personalised nutrition service providers & & \\
\hline Family doctor/ GP & 0.028 & 0.025 \\
\hline Private health organisations & 0.017 & 0.180 \\
\hline Dietician/ nutritionist & 0.128 & $<0.001$ \\
\hline Supermarket & 0.084 & $<0.001$ \\
\hline
\end{tabular}


Table 4. Between-subjects effects on trust in and preferences for personalised nutrition sources

\begin{tabular}{|c|c|c|c|c|c|c|c|c|c|c|c|c|}
\hline \multirow{2}{*}{ Tests of Between-Subjects Effects } & \multicolumn{3}{|c|}{ Service regulators } & \multicolumn{3}{|c|}{ Information providers } & \multicolumn{3}{|c|}{ Communication channels } & \multicolumn{3}{|c|}{ Service providers } \\
\hline & $F^{a}$ & $p$ & $\eta_{p}^{2}$ & $F^{a}$ & $p$ & $\eta_{p^{2}}$ & $F^{a}$ & $p$ & $\eta_{p}^{2}$ & $F^{a}$ & $p$ & $\eta_{p^{2}}^{2}$ \\
\hline Country & $15.293(8)$ & $<0.001$ & 0.013 & $9.444(8)$ & $<0.001$ & 0.008 & $62.497(8)$ & $<0.001$ & 0.052 & $50.557(8)$ & $<0.001$ & 0.042 \\
\hline Sex & $0.255(1)$ & 0.613 & 0.000 & $22.254(1)$ & $<0.001$ & 0.002 & $8.730(1)$ & 0.003 & 0.001 & $48.536(1)$ & $<0.001$ & 0.005 \\
\hline Age & $11.967(3)$ & $<0.001$ & 0.004 & $17.776(3)$ & $<0.001$ & 0.006 & $45.937(3)$ & $<0.001$ & 0.015 & $19.833(3)$ & $<0.001$ & 0.006 \\
\hline Education & $1.504(2)$ & 0.222 & 0.000 & $1.440(2)$ & 0.237 & 0.000 & $0.987(2)$ & 0.373 & 0.000 & $0.771(2)$ & 0.463 & 0.000 \\
\hline CountrySex & $0.915(8)$ & 0.503 & 0.001 & $1.147(8)$ & 0.328 & 0.001 & $1.424(8)$ & 0.181 & 0.001 & $3.289(8)$ & 0.001 & 0.003 \\
\hline Country*Age & $1.943(24)$ & 0.004 & 0.005 & $1.565(24)$ & 0.039 & 0.004 & $2.574(24)$ & $<0.001$ & 0.007 & $2.610(24)$ & $<0.001$ & 0.007 \\
\hline Country ${ }^{\star}$ Education & $1.138(16)$ & 0.312 & 0.002 & $1.093(16)$ & 0.354 & 0.002 & $1.657(16)$ & 0.047 & 0.003 & $1.249(16)$ & 0.221 & 0.002 \\
\hline Sex*Age & $0.264(3)$ & 0.851 & 0.000 & $0.127(3)$ & 0.944 & 0.000 & $1.228(3)$ & 0.298 & 0.000 & $3.201(3)$ & 0.022 & 0.001 \\
\hline Sex Education & $0.237(2)$ & 0.789 & 0.000 & $0.084(2)$ & 0.919 & 0.000 & $0.043(2)$ & 0.957 & 0.000 & $1.439(2)$ & 0.237 & 0.000 \\
\hline Age*Education & $1.951(6)$ & 0.069 & 0.001 & $1.583(6)$ & 0.147 & 0.001 & $0.956(6)$ & 0.454 & 0.001 & $0.905(6)$ & 0.490 & 0.001 \\
\hline Country ${ }^{*}$ Sex ${ }^{\star}$ Age & $1.145(24)$ & 0.283 & 0.003 & $1.313(24)$ & 0.140 & 0.003 & $1.370(24)$ & 0.107 & 0.004 & $1.069(24)$ & 0.371 & 0.003 \\
\hline Country*Sex*Education & $0.833(16)$ & 0.648 & 0.001 & $0.981(16)$ & 0.474 & 0.002 & $1.010(16)$ & 0.442 & 0.002 & $0.991(16)$ & 0.464 & 0.002 \\
\hline Country ${ }^{\star}$ Age ${ }^{\star}$ Education & $1.286(48)$ & 0.089 & 0.007 & $1.136(48)$ & 0.241 & 0.006 & $0.986(48)$ & 0.499 & 0.005 & $1.038(48)$ & 0.401 & 0.005 \\
\hline Sex ${ }^{*}$ ge $^{*}$ Education & $1.068(6)$ & 0.379 & 0.001 & $1.450(6)$ & 0.191 & 0.001 & $0.423(6)$ & 0.864 & 0.000 & $1.524(6)$ & 0.166 & 0.001 \\
\hline Country ${ }^{\star}$ Sex ${ }^{\star}$ Age ${ }^{\star}$ Education & $0.834(48)$ & 0.786 & 0.004 & $0.829(48)$ & 0.794 & 0.004 & $1.086(48)$ & 0.318 & 0.006 & $1.532(48)$ & 0.011 & 0.008 \\
\hline
\end{tabular}


Table 5. Within-subjects effects on trust in and preferences for personalised nutrition sources

\begin{tabular}{|c|c|c|c|c|c|c|c|c|c|c|c|c|}
\hline \multirow{2}{*}{$\begin{array}{l}\text { Tests of Within-Subjects Effects } \\
\text { (Greenhouse-Geisser) }\end{array}$} & \multicolumn{3}{|c|}{ Service regulators } & \multicolumn{3}{|c|}{ Information providers } & \multicolumn{3}{|c|}{ Communication channels } & \multicolumn{3}{|c|}{ Service providers } \\
\hline & $F^{b}$ & $p$ & $\eta_{p^{2}}$ & $F^{c}$ & $p$ & $\eta_{p^{2}}$ & $F^{d}$ & $p$ & $\eta_{p^{2}}^{2}$ & $F^{e}$ & $p$ & $\eta_{p^{2}}$ \\
\hline Source & $2031.684(5.8)$ & $<0.001$ & 0.181 & $81.658(9.2)$ & 0.001 & 0.206 & $1225.816(3.8)$ & $<0.001$ & 0.118 & $3870.573(2.8)$ & $<0.001$ & 0.297 \\
\hline Source ${ }^{*}$ Country & $.022(46.2)$ & $<0.001$ & 0.036 & $35.666(73.3)$ & $<0.001$ & 0.030 & $24.210(30.5)$ & $<0.001$ & 0.021 & $17.191(22.2)$ & $<0.001$ & 0.015 \\
\hline Source ${ }^{\star}$ Sex & 8) & .001 & 0.002 & $9.2)$ & $<0.001$ & 0.002 & $17.065(3.8)$ & $<0.001$ & 0.002 & $18.518(2.8)$ & $<0.001$ & 0.002 \\
\hline Source ${ }^{*}$ Age & 7.3) & 001 & 0.004 & $7.5)$ & $<0.001$ & 0.004 & $3.162(11.4)$ & $<0.001$ & 0.001 & $24.235(8.3)$ & $<0.001$ & 0.008 \\
\hline Source & 5) & .001 & 0.007 & $8.3)$ & $<0.001$ & 0.006 & $4.000(7.6)$ & $<0.001$ & 0.001 & $16.587(5.5)$ & $<0.001$ & 0.004 \\
\hline Source ${ }^{\star}$ Coun & $1.865(46.2)$ & $<0.001$ & 0.002 & $1.749(73.3)$ & $<0.001$ & 0.002 & $1.670(30.5)$ & 0.012 & 0.001 & $1.141(22.2)$ & 0.292 & 0.001 \\
\hline Source $^{*}$ Country ${ }^{*}$ Age & $1.831(138.5)$ & $<0.001$ & 0.005 & $1.632(219.8)$ & $<0.001$ & 0.004 & $1.620(91.6)$ & $<0.001$ & 0.004 & $1.477(66.5)$ & 0.007 & 0.004 \\
\hline Source ${ }^{\star}$ Country ${ }^{\star}$ Education & 1.709 (92.3) & $<0.001$ & 0.003 & $1.600(146.6)$ & $<0.001$ & 0.003 & $1.317(61.0)$ & 0.049 & 0.002 & $0.993(44.3)$ & 0.485 & 0.002 \\
\hline Source ${ }^{\star}$ Sex ${ }^{\star}$ Age & $1.358(17.3)$ & 0.145 & 0.000 & $1.535(27.5)$ & 0.036 & 0.001 & $1.153(11.4)$ & 0.313 & 0.000 & $2.396(8.3)$ & 0.013 & 0.001 \\
\hline Source*SexEducation & $1.337(11.5)$ & 0.193 & 0.000 & $1.092(18.3)$ & 0.352 & 0.000 & $0.730(7.6)$ & 0.658 & 0.000 & $1.486(5.5)$ & 0.184 & 0.000 \\
\hline Source ${ }^{\star}$ Age ${ }^{\star}$ Education & $1.552(34.6)$ & 0.020 & 0.001 & $1.126(55.0)$ & 0.243 & 0.001 & $0.866(22.9)$ & 0.646 & 0.001 & $0.505(16.6)$ & 0.950 & 0.000 \\
\hline Source ${ }^{\star}$ Country ${ }^{\star}$ Sex ${ }^{\star}$ Age & $1.047(138.5)$ & 0.334 & 0.003 & $0.843(219.8)$ & 0.957 & 0.002 & $0.988(91.6)$ & 0.512 & 0.003 & $1.308(66.5)$ & 0.047 & 0.003 \\
\hline Source ${ }^{\star}$ Country ${ }^{*}$ Sex Education & $1.126(92.3)$ & 0.192 & 0.002 & $1.067(146.6)$ & 0.275 & 0.002 & $1.302(61.0)$ & 0.057 & 0.002 & $0.945(44.3)$ & 0.576 & 0.002 \\
\hline Source ${ }^{*}$ Country ${ }^{\star}$ Age ${ }^{*}$ Education & $1.258(276.9)$ & 0.002 & 0.007 & $1.252(439.7)$ & $<0.001$ & 0.007 & $0.925(183.1)$ & 0.758 & 0.005 & $1.239(133.0)$ & 0.032 & 0.006 \\
\hline Source ${ }^{\star}$ Sex ${ }^{\star}$ Age ${ }^{\star}$ Education & $1.076(34.6)$ & 0.349 & 0.001 & $0.911(55.0)$ & 0.662 & 0.001 & $1.292(22.9)$ & 0.158 & 0.001 & $1.078(16.6)$ & 0.369 & 0.001 \\
\hline Source ${ }^{*}$ Country ${ }^{*}$ Sex $^{*}$ Age ${ }^{*}$ C & $1.017(276.9)$ & 0.412 & 0.005 & $1.021(439.7)$ & 0.369 & 0.005 & 183.1) & 0.208 & 0.006 & $1.090(133.0)$ & 0.225 & 0.006 \\
\hline
\end{tabular}

${ }^{*}$ Refers to the different service regulators, information providers, communication channels, or service providers sources. ${ }^{b}$ Degrees of freedom $(d f)$ for numerator in between parentheses; $d f$ for denominator $=52874.3 .{ }^{\circ} d f$ for numerator in between parentheses; $d f$ for denominator $=83949.0 .{ }^{d} d f$ for numerator in between parentheses; $d f$ for denominator $=34962.0$. ${ }^{e}$ df for numerator in between parentheses; $d f$ for denominator $=25392.3$ 
Table 6. Country effects: observed means and homogeneous subsets

\begin{tabular}{|c|c|c|}
\hline CoUNTRY & $\begin{array}{c}\text { Service } \\
\text { regulators }\end{array}$ & $\begin{array}{c}\text { Information } \\
\text { providers }\end{array}$ \\
\hline Germany & $3.07[\mathrm{~d}, \mathrm{e}]$ & $3.05[\mathrm{c}, \mathrm{d}, \mathrm{e}]$ \\
\hline Greece & $2.87[\mathrm{a}]$ & $2.94[\mathrm{a}]$ \\
\hline Ireland & $2.98[\mathrm{~b}, \mathrm{c}]$ & $3.09[\mathrm{~d}, \mathrm{e}]$ \\
\hline Netherlands & $3.04[\mathrm{c}, \mathrm{d}]$ & $3.03[\mathrm{~b}, \mathrm{c}, \mathrm{d}]$ \\
\hline Norway & $3.01[\mathrm{~b}, \mathrm{c}, \mathrm{d}]$ & $2.97[\mathrm{a}, \mathrm{b}]$ \\
\hline Poland & $2.87[\mathrm{a}]$ & $3.00[\mathrm{a}, \mathrm{b}, \mathrm{c}]$ \\
\hline Portugal & $2.96[\mathrm{~b}, \mathrm{c}]$ & $3.10[\mathrm{~d}, \mathrm{e}]$ \\
\hline Spain & $3.13[\mathrm{e}]$ & $3.12[\mathrm{e}]$ \\
\hline UK & $2.94[\mathrm{a}, \mathrm{b}]$ & $3.02[\mathrm{~b}, \mathrm{c}, \mathrm{d}]$ \\
\hline
\end{tabular}

For each item, means that share the same letter are not significantly different from one another. Homogeneous subsets of countries (per construct;; Tukey HSD) are presented with lowercase letters within square brackets, e.g. "[a,b]". Homogeneous subsets are indicated alphabetically starting at the ones with lowest means. 
Table 7. Actor/Channel-country effects: observed means and homogeneous subsets

\begin{tabular}{|c|c|c|c|c|c|c|c|c|c|}
\hline \multicolumn{10}{|c|}{ Trust in different personalised nutrition service regulators (consumer protection) } \\
\hline \multirow{2}{*}{ Service Regulator } & \multicolumn{9}{|c|}{ COUNTRY } \\
\hline & Germany & Greece & Ireland & Netherlands & Norway & Poland & Portugal & Spain & UK \\
\hline General practitioners (GPs) & $3.87[f](F)$ & $3.54[b, c](E)$ & $3.64[\mathrm{c}, \mathrm{d}, \mathrm{e}](\mathrm{G})$ & $3.66[\mathrm{~d}, \mathrm{e}](\mathrm{F})$ & $3.50[\mathrm{~b}](\mathrm{E})$ & $3.58[b, c, d, e](E)$ & $3.20[a](E)$ & $3.69[\mathrm{e}](\mathrm{F})$ & $3.57[b, c, d](G)$ \\
\hline Consumer organisations & $3.45[\mathrm{e}](\mathrm{E})$ & $3.32[b, c, d](D)$ & $3.22[a, b](E)$ & $3.36[\mathrm{c}, \mathrm{d}, \mathrm{e}](\mathrm{E})$ & $3.41[\mathrm{~d}, \mathrm{e}](\mathrm{D}, \mathrm{E})$ & $3.25[a, b](D)$ & $3.27[a, b, c](E, F)$ & $3.43[\mathrm{~d}, \mathrm{e}](\mathrm{E})$ & $3.17[\mathrm{a}](\mathrm{E})$ \\
\hline Universities & $3.24[a, b, c](D)$ & $3.50[\mathrm{~d}](\mathrm{E})$ & $3.35[\mathrm{c}](\mathrm{F})$ & $3.31[\mathrm{a}, \mathrm{b}, \mathrm{c}](\mathrm{E})$ & $3.32[b, c](C)$ & $3.20[\mathrm{a}](\mathrm{D})$ & $3.32[b, c](F)$ & $3.35[\mathrm{c}](\mathrm{D})$ & $3.22[a, b](E)$ \\
\hline The Department of Health/ National Health Service (NHS) & $3.07[c](C)$ & $2.55[\mathrm{a}](\mathrm{B})$ & $3.13[c](E)$ & $3.13[\mathrm{c}](\mathrm{D})$ & $3.40[\mathrm{~d}](\mathrm{C}, \mathrm{D})$ & $2.73[\mathrm{~b}](\mathrm{B})$ & $3.05[\mathrm{c}](\mathrm{D})$ & $3.08[\mathrm{c}](\mathrm{B})$ & $3.30[\mathrm{~d}](\mathrm{F})$ \\
\hline The European Commission & $2.68[a](B)$ & $3.10[\mathrm{c}, \mathrm{d}](\mathrm{C})$ & $3.02[\mathrm{c}](\mathrm{D})$ & $2.79[a, b](C)$ & $2.67[\mathrm{a}](\mathrm{B})$ & $2.88[b](C)$ & $3.03[c](D)$ & $3.16[d](C)$ & $2.72[\mathrm{a}](\mathrm{D})$ \\
\hline Health insurance companies & $3.22[\mathrm{e}](\mathrm{D})$ & $2.36[a](A)$ & $2.70[b, c](C)$ & $2.84[\mathrm{~d}](\mathrm{C})$ & $2.70[b, c](B)$ & $2.45[\mathrm{a}](\mathrm{A})$ & $2.41[\mathrm{a}](\mathrm{A})$ & $2.77[c, d](A)$ & $2.60[\mathrm{~b}](\mathrm{C})$ \\
\hline Food retailers & $2.62[\mathrm{~d}](\mathrm{B})$ & $2.29[\mathrm{a}](\mathrm{A})$ & $2.48[b, c](B)$ & $2.56[c, d](A)$ & $2.55[\mathrm{c}, \mathrm{d}](\mathrm{A})$ & $2.42[\mathrm{~b}](\mathrm{A})$ & $2.61[\mathrm{~d}](\mathrm{B})$ & $2.75[\mathrm{e}](\mathrm{A})$ & $2.52[b, c, d](B)$ \\
\hline Food manufacturers & $2.45[\mathrm{C}](\mathrm{A})$ & $2.30[a, b](A)$ & $2.28[a](A)$ & $2.65[\mathrm{~d}](\mathrm{B})$ & $2.50[\mathrm{c}](\mathrm{A})$ & $2.46[\mathrm{c}](\mathrm{A})$ & $2.77[\mathrm{e}](\mathrm{C})$ & $2.80[\mathrm{e}](\mathrm{A})$ & $2.42[b, c](A)$ \\
\hline \multicolumn{10}{|c|}{ Trust in different actors to provide accurate information about personalised nutrition } \\
\hline \multirow{2}{*}{ Information Source } & \multicolumn{9}{|c|}{ COUNTRY } \\
\hline & Germany & Greece & Ireland & Netherlands & Norway & Poland & Portugal & Spain & UK \\
\hline Your family doctor & $3.91[\mathrm{f}](\mathrm{H})$ & $3.83[\mathrm{~d}, \mathrm{e}, \mathrm{f}](\mathrm{K})$ & $3.87[e, f](l)$ & $3.67[b, c](l)$ & $3.59[\mathrm{a}, \mathrm{b}](\mathrm{H})$ & $3.55[\mathrm{a}](\mathrm{H})$ & $3.75[\mathrm{c}, \mathrm{d}](\mathrm{l})$ & $3.82[\mathrm{~d}, \mathrm{e}, \mathrm{f}](\mathrm{J})$ & $3.77[\mathrm{c}, \mathrm{d}, \mathrm{e}](\mathrm{l})$ \\
\hline Dieticians/ nutritionists & $3.37[\mathrm{a}](\mathrm{G})$ & $3.55[\mathrm{c}, \mathrm{d}, \mathrm{e}](\mathrm{J})$ & $3.63[d, e](H)$ & $3.50[\mathrm{~b}, \mathrm{c}](\mathrm{H})$ & $3.65[\mathrm{e}](\mathrm{H})$ & $3.51[\mathrm{c}](\mathrm{G}, \mathrm{H})$ & $3.63[\mathrm{~d}, \mathrm{e}](\mathrm{H})$ & $3.51[c, d](H)$ & $3.39[a, b](G, H)$ \\
\hline National Health Service (NHS) & $3.88[\mathrm{~h}](\mathrm{H})$ & $3.05[\mathrm{~b}](\mathrm{F})$ & $3.19[\mathrm{c}](\mathrm{E})$ & $2.88[\mathrm{a}](\mathrm{D})$ & $3.34[\mathrm{~d}, \mathrm{e}](\mathrm{G})$ & $3.48[f](G, H)$ & $3.29[\mathrm{c}, \mathrm{d}](\mathrm{F}, \mathrm{G})$ & $3.73[g](\mathrm{l})$ & $3.43[e, f](H)$ \\
\hline Consumer organisations & $3.41[\mathrm{c}](\mathrm{G})$ & $3.36[\mathrm{c}](\mathrm{I})$ & $3.30[b, c](E, F)$ & $3.40[\mathrm{c}](\mathrm{G})$ & $3.31[\mathrm{~b}, \mathrm{c}](\mathrm{F}, \mathrm{G})$ & $3.23[a, b](F)$ & $3.32[b, c](F, G)$ & $3.39[\mathrm{c}](\mathrm{G})$ & $3.18[\mathrm{a}](\mathrm{E})$ \\
\hline Friends and family & $3.47[\mathrm{c}](\mathrm{G})$ & $3.25[\mathrm{~b}](\mathrm{H}, \mathrm{I})$ & $3.45[c](G)$ & $3.28[\mathrm{~b}](\mathrm{F})$ & $3.08[a](D)$ & $3.50[\mathrm{c}](\mathrm{G}, \mathrm{H})$ & $3.24[\mathrm{~b}](\mathrm{E}, \mathrm{F})$ & $3.19[\mathrm{~b}](\mathrm{D}, \mathrm{E})$ & $3.40[\mathrm{c}](\mathrm{G}, \mathrm{H})$ \\
\hline Universities & $3.18[\mathrm{a}](\mathrm{F})$ & $3.48[\mathrm{~d}](\mathrm{J})$ & $3.37[\mathrm{c}](\mathrm{F}, \mathrm{G})$ & $3.30[b, c](F)$ & $3.24[a, b](E, F)$ & $3.15[\mathrm{a}](\mathrm{E})$ & $3.35[\mathrm{c}](\mathrm{G})$ & $3.32[\mathrm{~b}, \mathrm{c}](\mathrm{F}, \mathrm{G})$ & $3.24[a, b](E, F)$ \\
\hline Personal trainers & $3.13[\mathrm{a}](\mathrm{E}, \mathrm{F})$ & $3.17[\mathrm{a}](\mathrm{G}, \mathrm{H})$ & $3.38[\mathrm{~b}](\mathrm{F}, \mathrm{G})$ & $3.22[\mathrm{a}](\mathrm{E}, \mathrm{F})$ & $3.17[\mathrm{a}](\mathrm{D}, \mathrm{E})$ & $3.44[b](G)$ & $3.17[\mathrm{a}](\mathrm{D}, \mathrm{E})$ & $3.24[\mathrm{a}](\mathrm{E}, \mathrm{F})$ & $3.14[\mathrm{a}](\mathrm{E})$ \\
\hline Department of Health & $3.04[b](E)$ & $2.66[a](E)$ & $3.27[\mathrm{c}, \mathrm{d}](\mathrm{E}, \mathrm{F})$ & $3.16[b, c](E)$ & $3.35[\mathrm{~d}](\mathrm{G})$ & $2.76[a](C)$ & $3.13[b](D)$ & $3.12[b](D)$ & $3.32[\mathrm{~d}](\mathrm{F}, \mathrm{G})$ \\
\hline The European Commission & $2.67[a, b](C)$ & $3.10[\mathrm{~d}](\mathrm{F}, \mathrm{G})$ & $3.10[\mathrm{~d}](\mathrm{D})$ & $2.85[\mathrm{c}](\mathrm{C}, \mathrm{D})$ & $2.62[\mathrm{a}](\mathrm{C})$ & $2.86[\mathrm{c}](\mathrm{D})$ & $3.05[\mathrm{~d}](\mathrm{C})$ & $3.16[\mathrm{~d}](\mathrm{D}, \mathrm{E})$ & $2.78[b, c](D)$ \\
\hline News media & $2.82[\mathrm{e}](\mathrm{D})$ & $2.14[\mathrm{a}](\mathrm{A})$ & $2.69[\mathrm{c}, \mathrm{d}](\mathrm{C})$ & $2.77[\mathrm{~d}, \mathrm{e}](\mathrm{C})$ & $2.49[\mathrm{~b}](\mathrm{B})$ & $2.48[\mathrm{~b}](\mathrm{A})$ & $2.75[\mathrm{~d}, \mathrm{e}](\mathrm{B})$ & $2.63[\mathrm{c}](\mathrm{B})$ & $2.63[c](C)$ \\
\hline Online personalised nutrition companies & $2.50[\mathrm{a}](\mathrm{B})$ & $2.52[a, b](D)$ & $2.59[a, b, c](B, C)$ & $2.65[\mathrm{c}](\mathrm{B})$ & $2.49[\mathrm{a}](\mathrm{B})$ & $2.58[a, b, c](B)$ & $2.65[\mathrm{c}](\mathrm{A})$ & $2.66[\mathrm{C}](\mathrm{B}, \mathrm{C})$ & $2.64[b, c](C)$ \\
\hline Food retailers & $2.56[b, c, d](B, C)$ & $2.33[\mathrm{a}](\mathrm{B}, \mathrm{C})$ & $2.53[b, c](B)$ & $2.57[\mathrm{c}, \mathrm{d}](\mathrm{A})$ & $2.46[b, c](B)$ & $2.45[\mathrm{~b}](\mathrm{A})$ & $2.65[\mathrm{~d}, \mathrm{e}](\mathrm{A})$ & $2.74[\mathrm{e}](\mathrm{C})$ & $2.52[b, c](B)$ \\
\hline Social media & $2.41[a, b](A)$ & $2.41[a, b](C)$ & $2.54[c, d](B)$ & $2.62[\mathrm{~d}](\mathrm{A}, \mathrm{B})$ & $2.35[\mathrm{a}](\mathrm{A})$ & $2.60[\mathrm{~d}](\mathrm{B})$ & $2.61[\mathrm{~d}](\mathrm{A})$ & $2.54[c, d](A)$ & $2.48[b, c] A, B)$ \\
\hline Food manufacturers & $2.39[\mathrm{~b}](\mathrm{A})$ & $2.27[\mathrm{a}](\mathrm{B})$ & $2.34[a, b](A)$ & $2.55[\mathrm{c}](\mathrm{A})$ & $2.37[a, b](A)$ & $2.45[b, c](A)$ & $2.75[\mathrm{~d}](\mathrm{B})$ & $2.71[\mathrm{~d}](\mathrm{C})$ & $2.42[\mathrm{~b}](\mathrm{A})$ \\
\hline
\end{tabular}




\begin{tabular}{|c|c|c|c|c|c|c|c|c|c|}
\hline \multicolumn{10}{|c|}{ Preferences regarding personalised nutrition communication channels } \\
\hline \multirow{2}{*}{ Communication Channel } & \multicolumn{9}{|c|}{ COUNTRY } \\
\hline & Germany & Greece & Ireland & Netherlands & Norway & Poland & Portugal & Spain & UK \\
\hline Personal meeting & $2.52[\mathrm{~b}](\mathrm{D})$ & $3.70[f](C)$ & $3.34[\mathrm{e}](\mathrm{E})$ & $2.85[\mathrm{c}](\mathrm{D})$ & $3.15[\mathrm{~d}](\mathrm{E})$ & $3.26[\mathrm{~d}, \mathrm{e}](\mathrm{E})$ & $3.18[\mathrm{~d}, \mathrm{e}](\mathrm{D})$ & $2.32[\mathrm{a}](\mathrm{D})$ & $2.78[\mathrm{c}](\mathrm{F})$ \\
\hline Email contact from a named person & $2.41[\mathrm{a}](\mathrm{D})$ & $2.84[c, d](B)$ & $2.74[b, c](D)$ & $2.37[\mathrm{a}](\mathrm{C})$ & $2.45[\mathrm{a}](\mathrm{D})$ & $3.11[\mathrm{e}](\mathrm{D})$ & $2.68[b, c](C)$ & $2.93[\mathrm{~d}](\mathrm{C})$ & $2.62[b](E)$ \\
\hline Telephone call & $1.80[\mathrm{a}](\mathrm{B})$ & $2.50[e, f](A)$ & $2.37[\mathrm{~d}, \mathrm{e}](\mathrm{C})$ & $2.06[\mathrm{~b}](\mathrm{B})$ & $2.18[b, c](C)$ & $2.59[\mathrm{f}](\mathrm{B})$ & $2.32[\mathrm{c}, \mathrm{d}](\mathrm{B})$ & $2.03[\mathrm{~b}](\mathrm{B})$ & $2.13[b](D)$ \\
\hline Automated internet service & $1.95[\mathrm{a}](\mathrm{C})$ & $2.46[c](A)$ & $2.04[\mathrm{a}](\mathrm{A})$ & $2.00[\mathrm{a}](\mathrm{B})$ & $1.98[\mathrm{a}](\mathrm{B})$ & $2.71[\mathrm{~d}](\mathrm{C})$ & $2.33[b, c](B)$ & $2.23[\mathrm{~b}](\mathrm{C})$ & $2.01[\mathrm{a}](\mathrm{C})$ \\
\hline Apps & $1.74[\mathrm{a}](\mathrm{B})$ & $2.41[\mathrm{C}](\mathrm{A})$ & $2.15[\mathrm{~b}](\mathrm{B})$ & $1.84[\mathrm{a}](\mathrm{A})$ & $1.86[\mathrm{a}](\mathrm{A})$ & $2.72[\mathrm{~d}](\mathrm{C})$ & $2.13[\mathrm{~b}](\mathrm{A})$ & $2.04[\mathrm{~b}](\mathrm{B})$ & 1.87 [a] (B) \\
\hline Video call (e.g. Skype) & $1.61[\mathrm{a}](\mathrm{A})$ & $2.48[\mathrm{e}](\mathrm{A})$ & $2.01[c](A)$ & $1.80[\mathrm{~b}](\mathrm{A})$ & $1.86[\mathrm{~b}](\mathrm{A})$ & $2.46[\mathrm{e}](\mathrm{A})$ & $2.18[\mathrm{~d}](\mathrm{A})$ & $1.73[a, b](A)$ & $1.75[\mathrm{a}, \mathrm{b}](\mathrm{A})$ \\
\hline \multicolumn{10}{|c|}{ Preferences regarding personalised nutrition service providers } \\
\hline \multirow{2}{*}{ Service Provider } & \multicolumn{9}{|c|}{ COUNTRY } \\
\hline & Germany & Greece & Ireland & Netherlands & Norway & Poland & Portugal & Spain & UK \\
\hline Family doctor/ GP & $3.36[\mathrm{~b}](\mathrm{D})$ & $3.78[\mathrm{c}](\mathrm{D})$ & $3.71[\mathrm{c}](\mathrm{D})$ & $3.20[\mathrm{a}](\mathrm{D})$ & $3.36[\mathrm{~b}](\mathrm{D})$ & $3.38[\mathrm{~b}](\mathrm{C})$ & $3.72[\mathrm{c}](\mathrm{D})$ & $3.46[\mathrm{~b}](\mathrm{D})$ & $3.42[b](D)$ \\
\hline Dietician/ Nutritionist & $2.72[\mathrm{a}](\mathrm{C})$ & $3.60[\mathrm{e}](\mathrm{C})$ & $3.43[\mathrm{~d}](\mathrm{C})$ & $2.94[b](C)$ & $3.20[c](C)$ & $3.51[\mathrm{~d}, \mathrm{e}](\mathrm{D})$ & $3.49[\mathrm{~d}, \mathrm{e}](\mathrm{C})$ & $3.04[b](C)$ & $2.92[b](C)$ \\
\hline Private health organisations & $2.41[\mathrm{a}](\mathrm{B})$ & $2.88[\mathrm{c}](\mathrm{B})$ & $2.88[\mathrm{c}](\mathrm{B})$ & $2.38[a](B)$ & $2.58[\mathrm{~b}](\mathrm{B})$ & $3.06[\mathrm{~d}](\mathrm{B})$ & $3.00[\mathrm{c}, \mathrm{d}](\mathrm{B})$ & $2.61[\mathrm{~b}](\mathrm{B})$ & $2.49[a, b](B)$ \\
\hline Supermarket & $1.89[\mathrm{~b}, \mathrm{c}](\mathrm{A})$ & $1.94[\mathrm{~b}, \mathrm{c}, \mathrm{d}](\mathrm{A})$ & 2.04 [d] (A) & $1.90[\mathrm{~b}, \mathrm{c}, \mathrm{d}] \mathrm{(A)}$ & $1.71[\mathrm{a}](\mathrm{A})$ & $1.99[\mathrm{c}, \mathrm{d}](\mathrm{A})$ & $2.37[\mathrm{e}](\mathrm{A})$ & $1.84[a, b](A)$ & $1.87[\mathrm{~b}, \mathrm{c}](\mathrm{A})$ \\
\hline
\end{tabular}

For each item, means that share the same letter are not significantly different from one another. Homogeneous subsets of countries (per item) are presented with lowercase letters within square brackets, e.g. "[a,b]", whereas homogeneous subsets of items (per country) are presented with uppercase letters within curved brackets, e.g. "(A,B)". Homogeneous subsets are indicated alphabetically starting at the ones with lowest means. 